Article

\title{
Exploring the Current Practices and Future Needs of Marine Engineering Education in Bangladesh
}

\author{
Hasan Mahbub Tusher ${ }^{1}$ (D), Amit Sharma ${ }^{1}$, Salman Nazir ${ }^{1, *(D)}$ and Ziaul Haque Munim ${ }^{2}$ \\ 1 Training and Assessment Research Group (TARG), Department of Maritime Operations, \\ University of South-Eastern Norway, 3184 Borre, Norway; hasan.m.tusher@usn.no (H.M.T.); \\ amit.sharma@usn.no (A.S.) \\ 2 Maritime Logistics Research Group (MARLOG), Department of Maritime Operations, \\ University of South-Eastern Norway, 3184 Borre, Norway; ziaul.h.munim@usn.no \\ * Correspondence: salman.nazir@usn.no
}

check for updates

Citation: Tusher, H.M.; Sharma, A.; Nazir, S.; Munim, Z.H. Exploring the Current Practices and Future Needs of Marine Engineering Education in Bangladesh. J. Mar. Sci. Eng. 2021, 9, 1085. https://doi.org/10.3390/ jmse9101085

Academic Editor: Sergei Chernyi

Received: 25 August 2021

Accepted: 2 October 2021

Published: 5 October 2021

Publisher's Note: MDPI stays neutral with regard to jurisdictional claims in published maps and institutional affiliations.

Copyright: (C) 2021 by the authors Licensee MDPI, Basel, Switzerland. This article is an open access article distributed under the terms and conditions of the Creative Commons Attribution (CC BY) license (https:// creativecommons.org/licenses/by/ $4.0 /)$.

\begin{abstract}
Developing countries, despite being the major suppliers of maritime manpower, lag in their future-proof competence development. This study explores whether the current maritime education and training (MET) practices for marine engineering education in a developing nation are perceived as sufficient by the early-stage marine engineers. The current competence requirements set by the Standards of Training, Certification and Watchkeeping for Seafarers (STCW'74 as amended) are compared and contrasted against the current MET practices as well as the future needs for remotely controlled autonomous ship operations. Bangladesh, a maritime nation in the Southeast Asia region was selected as a developing nation for this study. An online survey was conducted among early-stage professional marine engineers. The analysis of 62 valid responses revealed that current MET practices are significantly perceived to be satisfactory for acquiring non-technical competencies, such as being proficient in the English language, but are less satisfactory for instilling technical competencies such as of electrical and electronics, knowledge regarding seaworthiness of ships, as well as medical first aid. In addition, the findings highlight the perceived gaps in existing marine engineering education as well as the need for future studies focused on re-training the future maritime workforce that could potentially improve MET strategies and practices in the developing nations.
\end{abstract}

Keywords: competency; training; maritime simulators; STCW; future skills; autonomous ships

\section{Introduction}

The shipping industry is frequently termed as the lifeblood of the global economy, carrying almost $90 \%$ of traded goods worldwide [1]. The seafarers working onboard merchant ships serve as an important link between efficient operation and workplace safety within the industry. Maritime Education and Training (MET) plays a crucial role in instilling required skills and competencies in seafarers to perform efficiently in their workplaces [2]. Better on-the-job task performance of the involved personnel depends on their high quality education and training, whereas sub-standard training leads to accidents and incidents in ships [3].

The International Convention on Standards of Training, Certification and Watchkeeping for Seafarers (STCW'74 as amended) mandated by the International Maritime Organization (IMO) dictates the minimum standards of seafarers' education and training all over the world [4]. There are numerous MET institutions globally that strive to equip seafarers with appropriate knowledge, skills, and attitudes in accordance to STCW'74 as amended to be able to operate efficiently in their workplaces [5]. However, with the emergence of new technology and changing work environments, the standards of education and training are also evolving. These disruptions could potentially challenge the MET institutions with the need for constant re-evaluation of their current practices and future strategies. 
Differing statistics show how human error constitutes the majority of contributing factors in maritime accidents [6]. Autonomous ships are pitched as a recent solution that promises to reduce operational risks and increase efficiency by eleminating the onboard crew-thus, human related error $[7,8]$. Although there have been wider debates around the role of various factors in accident causation, the actions performed by the crew members have important ramifications. With the advances in the industry-such as automation and digitalization - the focus is again drawn to the need for appropriate training or re-training of seafarers-a prime responsibility of MET institutions. The inclusion of autonomous ships in the current maritime operational landscape would mean that the competency requirement of the the present workforce would also need to be redefined, which, in turn, would act as a driver of change in the stipulated competency regualtions (i.e., STCW) as well as in future MET practices [9,10]. For example, it is already hypothesized that prospective seafarers must be trained to account for the technical, environmental, and legislative aspects of future autonomous work environments [11].

IMO plays an instrumental role in overseeing the global regulatory requirements in the maritime industry, which necessiates exploring potential new regulations with the emergence of autonomous shipping technologies. Consequently, on the 98th session of Maritime Safety Committee in June 2017 at IMO headquarters in London, a scoping exercise to identify regualtory avenues related to Maritime Autonomous Surface Ships (MASS) was initiated. The focus of the scoping exercise was to explore the various aspects of human involvement as well as legal and environmental implications. The STCW convention, being one of the key pillars of the maritime regulatory framework providing a benchmark for standard competency requirement for seafarers worldwide, received extensive contemplation in the autonomous shipping context [12].

Merchant ships today operate with high reliability and sophisticated equipment both in navigation and in engine room operations. Marine engineers are responsible for the operation and maintenance of shipboard propulsion systems, electrical equipment, and any other associated technical systems [13,14]. The minimum competency requirement of marine engineering officers and ratings are delineated in the STCW convention that all signatory flag states are bound to follow. In the context of autonomous ships, the future skills and competency requirements for navigation officers are explored in a study by Sharma et al. (2019) [15]. However, little is known about how the competency of future marine engineers will pan out in the coming decades. Different studies suggest that MET in the developed countries (e.g., USA, UK, Japan, South Korea, etc.) exceeds the requirement set by STCW, whereas the developing nations (e.g., India, Vietnam, Myanmar, Bangladesh, etc.) struggle to meet the minimum standards, especially due to the shortage of qualified professionals and/or lack of sufficient infrastructure [16-18]. Therefore, it is crucial to address the lack of MET sufficiency in developing countries in order to meet the skill and competency demands of the future.

There are close to 1.7 million certified and qualified seafarers worldwide according to the International Chamber of Shipping (2020) [19]. Developing nations account for more than half of global supply with approximately 900,000 seafarers [20], Philippine being the largest with a global 30\% stake in crew supply [21]. Bangladesh, the country used as a case study here, is a small seafaring nation from the developing world compared to China, Philippines, India, Indonesia, and the Russian federation, with only 14,054 active seafarers [22,23]. Because developing countries are the significant supplier of maritime manpower [24], it is crucial that the current and future trends of MET in those countries follow the technological advancements in the workplaces to facilitate smooth transition of the operational landscape of the shipping industry on a global scale.

The goal of this study is to explore if the current MET practices are perceived as sufficient by early-stage marine engineers for acquiring the engineering competencies as required by STCW (STCW'74 as amended). In addition, the perception regarding the relevance of current competency requirements in the future is also explored. An online 
survey among early-stage marine engineers was employed where the case of Bangladesh is used as a representation of the developing countries.

The contents of this study are arranged as follows: Section 2 provides information about the current practices in MET institutions with regards to the requirements as stipulated in STCW; Section 3 elicits the potential changes in marine engineers' role as well as the need for new skills with the advent of autonomous technologies in the shipping industry. Sections 4-6 contain information about the methods, results, and discussion on the results, respectively, before a summary of the findings of the study are presented in the conclusion section.

\section{Marine Engineering Education and STCW}

Traditionally, MET providers cater to the STCW regulations when developing curricula and arranging education and training programs. MET institutions from around the world offer diverse routes to become a professional marine engineer, especially through either of two educational streams: (1) mariner license oriented programs and (2) mariner license and academic degree oriented programs [25]. Both types of programs tend to comprise a certain period (6-18 months) of sea service included in the main curriculum depending on the local regulations, in order to provide hands-on experience to the future marine engineers. Through these programs differ in content and duration, the core courses are identical for both programs in most cases. Mathematics and basic science, mechanics, materials, thermodynamics, fluids, basic electricity, propulsion plant, power plant, and naval architecture are some of the common blocks of modules included in marine engineering curricula all over the world, whereas social science and some physical fitness courses may be offered optionally [25].

MET is primarily overseen by the local flag state administrators while the curriculum development and the implementation are guided by the STCW' 74 as amended. It is stipulated that all seafaring officers should hold a certificate of competency approved by the local authorities that are formalized based on STCW regulations [11]. This STCW convention was later revised multiple times to best suit the seafaring needs and on-thejob competence requirement along with the required knowledge, understanding, and proficiency (KUP) for seafarers.

The STCW convention with 2010 Manilla amendments comprises both mandatory standards (in Part-A) and recommended guidance (in Part-B) for education and training of marine engineers. The expected minimum standard of competence along with associated learning objectives and assessment criteria for operation, management, and support level marine engineers are delineated in Table A-III/1 through Table A-III/5 in STCW Chapter III [4]. Minimum requirements of STCW competences for marine engineer officers in an operational role are listed below:

1. Maintain a safe engineering watch;

2. Use English in written and oral form;

3. Use internal communication systems;

4. Operate main and auxiliary machinery and associated control systems;

5. Operate fuel, lubrication, ballast and other pumping systems and associated control systems;

6. Operate electrical, electronic and control systems;

7. Maintenance and repair of electrical and electronic equipment;

8. Appropriate use of hand tools, machine tools and measuring instruments for fabrication and repair on board;

9. Maintenance and repair of shipboard machinery and equipment;

10. Ensure compliance with pollution-prevention requirements;

11. Maintain seaworthiness of the ship;

12. Prevent, control and fight fires on board;

13. Operate life-saving appliances required;

14. Apply medical first aid on board ship; 
15. Monitor compliance with legislative requirements;

16. Application of leadership and teamworking skills;

17. Contribute to the safety of personnel and ship.

The goal of these requirements was to provide a common ground of minimum standard for MET, which the signatory countries were obliged to meet or exceed. In addition, this would also allow seafarers to be able to gain and demonstrate required competence at a level that is internationally accepted [4].

Nevertheless, the emergence of new technologies necessitates retraining of the existing workforce. This trend of retraining seafarers has been observed on previous occasions where marine engineering education evolved to accommodate the use of high-tech control equipment on shipboard operations [26]. The increasing use of electrical systems in the marine power systems and the integration of marine propulsion to the shipboard electrical systems necessitated marine engineers to become conversant with those systems. As a result marine engineering education at bachelor level had to assimilate electrical engineering topics in addition to the knowledge from mechanical engineering and naval architecture domains [27]. Similarly, the emergence of autonomous technologies in shipping industry also has obvious repercussions in MET and beyond.

\section{Impacts of MASS on Marine Engineering Education}

The impact of MASS technology on MET has been a topic of research in recent years. However, according to Jo and D'agostini (2020) [28], most studies related to the implementation of STCW in developing nations, especially in Asian countries, focus on seafarer employment. These studies also report that future technologies will create new jobs that will offset the negative effect on seafarers' employment, provided future seafarers are equipped with emerging skills (i.e., ICT, programming) where traditional competences may lose relevance. However, a comprehensive competency analysis is lacking in the literature that could give clear indication about how the future landscape of marine engineering education may look in the context of autonomous shipping, partly since the concept of autonomous shipping itself has not yet matured. As a result, there is still a general lack of understanding among MET providers on how to analyze the training needs for future seafarers [29]. Therefore, it is necessary to streamline the practical and regulator aspects along with mitigating the gaps in MET keeping the autonomous future in the horizon.

Attempts have been made to address these emerging aspects related to autonomous shipping from differing organizational and regulatory authorities starting with the classification of the same to better address the requirements on each level. Lloyd's Register defined six (06) levels of autonomy in the ShipRight procedure guidance for autonomous ships [30]. DNV GL also classified autonomous ships for the ease of enforcing guidelines in the future [31]. While classification societies and local regulators are focusing on different automation aids and decision support systems in determining different levels of autonomous ships, the IMO has set its focus solely on human involvement in shipping operation. In the 100th session of IMO's Maritime Safety Committee, as a part of the scoping exercise [32], IMO has differentiated four (04) levels of autonomy based on varying degree of human involvement (see Table 1). 
Table 1. Levels of autonomy in MASS by IMO and associated human roles [33].

\begin{tabular}{cccl}
\hline Degrees & Name & Human Presence Onboard & Description and Human Role \\
\hline Degree 1 & $\begin{array}{c}\text { Ship with automated process } \\
\text { and decision support }\end{array}$ & Yes & $\begin{array}{l}\text { Onboard crew oversees ships' operation, control } \\
\text { systems and functions }\end{array}$ \\
\hline Degree 2 & $\begin{array}{c}\text { Remotely controlled with } \\
\text { seafarers onboard }\end{array}$ & Yes & $\begin{array}{l}\text { Ship is controlled from a remote facility while } \\
\text { onboard crew is present to takeover operation } \\
\text { and control if required }\end{array}$ \\
\hline Degree 3 & $\begin{array}{c}\text { Remotely controlled without } \\
\text { seafarers onboard }\end{array}$ & No & $\begin{array}{l}\text { Ship is controlled from a remote facility without } \\
\text { any seafarer onboard and human intervention is } \\
\text { possible from shore control centre }\end{array}$ \\
\hline Degree 4 & Fully autonomous & No & $\begin{array}{l}\text { Ship is operated and controlled by itself and is } \\
\text { able to make decision and determine actions } \\
\text { without any direct supervision from } \\
\text { human operators }\end{array}$ \\
\hline
\end{tabular}

In addition, the converging output of the overall scoping exercise will essentially address MET strategies to ensure future readiness of the seafarers.

Marine engineers today already work in highly automated engine rooms with unattended machinery spaces (UMS) where the engine room remains unmanned during a certain period of the day maintaining the risk profile of the ship. Here, engineers are required to take supervisory roles in their day-to-day tasks and monitor different parameters of propulsion, power generation, cargo gears, pumps, alarms, fire extinguishing systems, and associated machineries used in the overall operation [34]. Based on the classification of autonomous ships presented in Table 1, most ships operating today fall under degree-1 in the scale of autonomy, where shipboard crew are responsible for operation and control functions in ships. At an advanced level of autonomy, shipboard crews will only take over operation and control of systems if required under degree- 2 operations while on a more advanced modes (i.e., in degree- 3 or degree- 4 operations), shipboard crews become irrelevant as ships would be either remotely controlled from shore or would become selfsufficient in decision making without any human intervention. In these remote-controlled set-ups, shipboard "operation and control" activities would become partially redundant for marine engineers, shifting their responsibilities towards higher level supervision tasks. Consequently, hands-on activities such as shipboard "repair and maintenance tasks" would become fully redundant for marine engineers [29]. Therefore, it is evident that current MET practices that stress on gaining competence on shipboard "operation and control" as well as shipboard "repair and maintenance" may not benefit marine engineers in the future.

Moreover, full-scale implementation of MASS may cause loss of onboard seafarers' job and increase new shore-based employment opportunities [28]. Those future seafarers (both navigators and engineers) would require ICT, programming and even gaming skills along with traditional seafaring competences $[35,36]$. Thus, the MET providers are faced with a two-fold challenge; first, to satisfy STCW requirements and then to facilitate practical experience onboard to advance in a seafaring career [11].

Transitional shifts within any industry impose a challenge to maintain a steady supply of competent workers. Unlike the traditional academic curriculum, the MET takes a vocational approach, focusing on the acquisition of practical skills and specific competence development, whereas the increasing global trend is to equip students with necessary knowledge leading to certain academic qualifications [37]. Nevertheless, the challenges associated with flexibility, responsiveness, and assurance of lifelong inclusive and equitable maritime education for the unpredictable future remains [11].

\section{Methods}

An online survey was carried out to understand seafarers' perception on the suitability of current MET practices as well as their future relevance. Early-stage professional marine 
engineers with the Certificate of Competency (COC, Class-3) and a maximum of 10 years of professional experience were sampled during the survey. The digital platform "Cognito forms" was used to conduct the survey and the form was open for participation from January through April of 2021. No personally identifiable data were collected. The link to the online survey was distributed via emails and posted in several social media groups targeting marine engineers. A total of 17 mandatory competencies for marine engineers as mandated in STCW Part-A, chapter-III, table A-III/1 (specification of minimum standard of competence for officers in charge of an engineering watch in a manned engine-room or designated duty engineers in a periodically unmanned engine-room [4]) were used in the survey to be rated against the following two statements:

a. Current Maritime Education and Training (MET) in Bachelor level is sufficient for developing this competence.

b. This competence is relevant for future Degree 2 level of autonomy (remotely controlled ship with seafarers onboard).

Both statements represent the "current MET sufficiency" and the "future relevance", respectively, for each corresponding competence. Only the "degree-2 level of autonomy (remotely controlled with seafarers' onboard)" is used as a probe in question b because other higher levels of autonomy (i.e., degree 3 and degree 4) do not involve humans working onboard. A Likert Scale of 1-5, 1 being "strongly disagree" and 5 being "strongly agree", was used as a rating scale for each of the 17 competencies.

A total of 75 participants responded the survey, among which seven were removed either due to more experience (in excess of 10 years) or their country of origin as this study was aimed at a particular demographic of marine engineers. Six responses were omitted due to straight lining. The remaining 62 samples were analyzed for the final output (see demographic overview in Table 2). Paired samples test is recommended when comparing means of a variable under two conditions based on data collected from the same participants [38]. Therefore, the mean score of the ratings for each competence were compared and paired sampled $t$-test of those means was performed to elicit any statistically significant difference between the statements (a) and (b) from above.

Table 2. Demographics of survey participants.

\begin{tabular}{ll}
\hline Description & Value \\
\hline Number of total respondents & 75 \\
Number of valid responses & 62 \\
Professional experience & 52 respondents with 1-5 years of experience \\
Maximum professional qualification & 10 respondents with 5-10 years of experience \\
Location & Bangladesh \\
\hline
\end{tabular}

\section{Results}

It is observed that the difference between the mean scores for "current MET sufficiency" and "future relevance" vary depending on the competence (see Table 3). Positive difference with a higher mean score for "current MET sufficiency" indicates that the current MET practices are perceived to be sufficient by the early-stage marine engineers for the corresponding competencies (i.e., the competencies 1,2, 4, and 16). In contrast, negative difference with higher mean score for "future relevance" indicate that the corresponding competencies (i.e., the competencies $3,5,6,7,8,9,10,11,12,13,14$, and 17) are perceived to be highly relevant in the future to efficiently operate degree-2 autonomous ships (see Figure 1). 
Table 3. Comparison of mean scores of statements related to STCW competence.

\begin{tabular}{|c|c|c|c|c|}
\hline STCW Competence & $\begin{array}{l}\text { (i) Current MET } \\
\text { Sufficiency }\end{array}$ & $\begin{array}{l}\text { (ii) Future } \\
\text { Relevance }\end{array}$ & $\begin{array}{l}\text { Difference } \\
\text { (i)-(ii) }\end{array}$ & $\begin{array}{l}\text { Paired } t \text {-Test } \\
(p \text {-Value })\end{array}$ \\
\hline 1: Maintain a safe engineering watch & 3.548 & 3.339 & 0.210 & 0.1450 \\
\hline 2: Use English in written and oral form & 4.097 & 3.726 & $0.371^{* * *}$ & 0.0077 \\
\hline 3: Use internal communication systems & 3.806 & 3.823 & -0.016 & 0.8710 \\
\hline $\begin{array}{l}\text { 4: Operate main and auxiliary machinery and associated } \\
\text { control systems }\end{array}$ & 3.387 & 3.323 & 0.065 & 0.6501 \\
\hline $\begin{array}{l}\text { 5: Operate fuel, lubrication, ballast and other pumping systems } \\
\text { and associated control systems }\end{array}$ & 3.500 & 3.613 & -0.113 & 0.4234 \\
\hline 6: Operate electrical, electronic and control systems & 2.935 & 3.274 & $-0.339^{* *}$ & 0.0184 \\
\hline $\begin{array}{l}\text { 7: Maintenance and repair of electrical and electronic } \\
\text { equipment }\end{array}$ & 2.806 & 3.226 & $-0.419^{* * *}$ & 0.0076 \\
\hline $\begin{array}{l}\text { 8: Appropriate use of hand tools, machine tools and measuring } \\
\text { instruments for fabrication and repair on board }\end{array}$ & 3.581 & 3.597 & -0.016 & 0.9053 \\
\hline $\begin{array}{l}\text { 9: Maintenance and repair of shipboard machinery and } \\
\text { equipment required }\end{array}$ & 3.516 & 3.597 & -0.081 & 0.5917 \\
\hline 10: Ensure compliance with pollution-prevention requirements & 4.000 & 4.032 & -0.032 & 0.6982 \\
\hline 11: Maintain seaworthiness of the ship & 3.500 & 3.742 & $-0.242 *$ & 0.0541 \\
\hline 12: Prevent, control and fight fires on board & 3.855 & 3.952 & -0.097 & 0.4187 \\
\hline 13: Operate life-saving appliances required & 3.742 & 3.887 & -0.145 & 0.1916 \\
\hline 14: Apply medical first aid on board ship & 3.274 & 3.597 & $-0.323^{* *}$ & 0.0188 \\
\hline 15: Monitor compliance with legislative requirements & 3.500 & 3.500 & 0.000 & 1.0000 \\
\hline 16: Application of leadership and teamworking skills & 3.855 & 3.806 & 0.048 & 0.7354 \\
\hline 17: Contribute to the safety of personnel and ship & 3.790 & 3.968 & -0.177 & 0.1393 \\
\hline
\end{tabular}

${ }^{*} p<0.10,{ }^{* *} p<0.05,{ }^{* * *} p<0.01$.

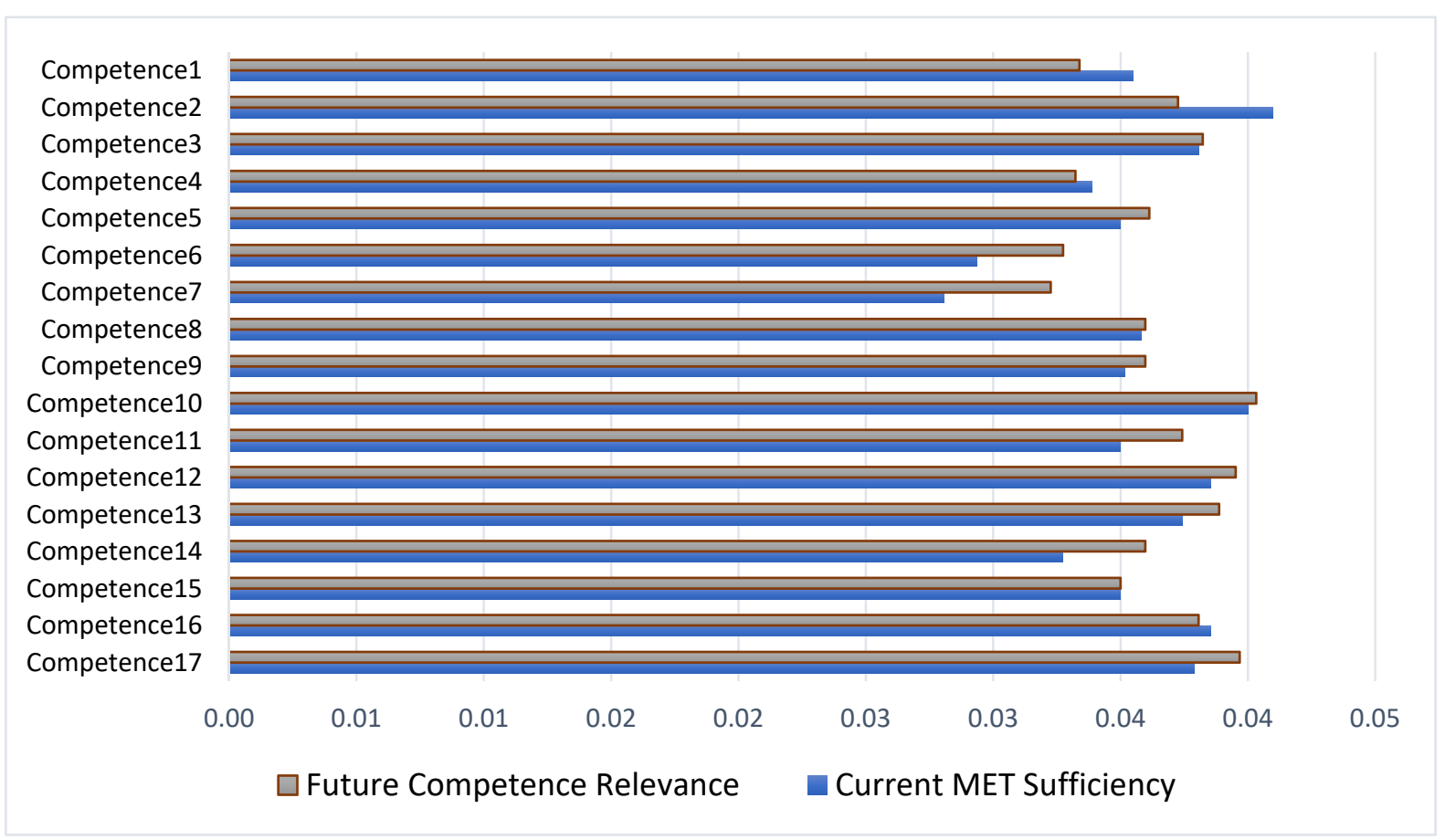

Figure 1. Radar plotted values for "current MET sufficiency" and "future competence relevance".

Further, a paired sample $t$-test $(p<0.10)$ between the two means indicate that there is a statistically significant difference between the mean scores of "current MET sufficiency" and "future relevance" for the competences $2,6,7,11$, and 14, all of which has negative mean difference except for competence 2 (see Table 3 ). 


\section{Discussion}

The results indicate a mixed output about the sufficiency of current MET practices in Bangladesh. The consensus among early-stage marine engineers is that a few required competencies as stipulated in the STCW convention are sufficiently addressed within the current MET framework of Bangladesh while some others are not. Concurrently, a couple of less emphasized competencies are perceived as more relevant in the context of future autonomous shipping. For example, competence 6, i.e., being able to operate electrical, electronic and control systems, is not sufficiently addressed in the current MET practices but is identified as a crucial competence for future remote-controlled ships with seafarers onboard as highlighted in this study and hypothesized by Lokuketagoda (2018) as well [29]. Similarly, respondents agree that few competencies such as, competence 7-being able to maintain and repair of electrical and electronic equipment, competence 11-being able to maintain seaworthiness of ship, and competence 14-being able to apply medical first aid on board ship, will be significantly relevant for the future degree- 2 autonomous shipping operations compared to other competencies. However, they generally tend to disagree about the current MET sufficiency for addressing competence 6 and competence 7 .

Curriculum design for shipping industry is influenced mostly by technological integration and innovation in the industry [39]. Therefore, the lack of sufficient support from MET institutions to gain required competencies while higher perceived relevance of them could mean that the MET institutions are not prepared for the potential innovative changes in the industry. The results depict that the early-stage professional marine engineers from Bangladesh agree about the insufficiency of current MET infrastructure for education and training related to the operation and maintenance of electrical systems.

Surprisingly, the future relevance of competencies 6 and 7 is also perceived as low compared to other highly future-relevant competencies. This could be attributed to the general lack of clarity among professionals related to future degree-2 autonomous shipping operations. Though the electrical engineer onboard is responsible for the operation and maintenance of electrical equipment, marine engineers are required to undertake those tasks in ships where a dedicated electrical engineer is not available, and the scenario is increasingly common nowadays onboard ships. The importance of knowledge and skills related to "electrical, electronic and control engineering" for future remote-controlled shipping operations is stressed in scientific literature as well [29]. However, based on the perceived need of the competence related to electrical equipment for future shipping operations, the crew dynamics may also change where an electrical engineer could be carried onboard or employing a shore personnel with electrical engineering competence would be a necessity.

Competence 11-being able to maintain seaworthiness of the ship, is also perceived to be addressed in current MET curriculum with slightly more relevance in the future. This competence requires seafarers to have knowledge, understanding, and proficiency about ship stability including trim, stress tables, diagrams, stress calculating equipment, fundamentals of watertight integrity, intact buoyancy, etc., and ship construction such as general knowledge about principal structural members of a ship and different nomenclature, etc. As depicted by the results, such knowledge related to seaworthiness of the ship would still remain relevant in the future degree-2 autonomous ships even though humans would take supervisory role in ships' operation onboard.

In contrast, competence 2-being able to use English in written and oral form-is perceived to be satisfactorily addressed by the current MET practices, receiving the highest score from the early-stage professional marine engineers. Therefore, it is apparent that the need to prioritize maritime English in MET curriculum in Bangladesh as expressed in previous studies $[40,41]$ has been receiving appropriate attention. The notion why English competence is perceived as slightly less relevant for future autonomous operations is probably linked with the fact that the automated systems will take over much of the human-human communication needs in an automated workplace by infusing non-verbal communication in daily interactions [42]. 
The general data, apart from the statistically significant measures of the results, indicate that broadly no mean score for current MET sufficiency exceeded 4.00 except for competencies 2 and 10. Therefore, the need for overall improvement in future MET strategies to address all required STCW competencies for marine engineers is warranted for the country under consideration. A potential strategy could be to start with the competencies with most negative differences from Table 3 first. Thus, the emergent competency requirements as perceived in light of the future autonomous ships would be addressed simultaneously with the current needs.

Maritime education generally consists of two phases. The first phase is considered as foundation training that takes place in maritime training academies and institutes. The core aspects of navigation, mathematics and other engineering subjects, along with basic ship construction, ship stability, and cargo handling are introduced in the first phase forming the "Phase-I Sea Training" as required by STCW. The Phase-II focuses on Navigation or Engineering Officer Competency exams and corresponds to higher-level knowledge and competency including watchkeeping duties onboard, which continue throughout a seafarer's career $[4,43]$. Therefore, increasing the MET sufficiency would mean facilitating the learning process in both phases of maritime education.

Moreover, in order to execute proper MET standards commensurate with the emerging industry standard, MET institutions should adopt new education and training technologies, update training programs to cover new requirements, cover all stage of MET to ensure continuous education, opt for a balance, and match strategy along with the local maritime administrators [43]. Digital high-tech training tools such as virtual reality (VR), augmented reality (AR), mixed reality (MR), and other forms of immersive media would undergo more development and implementation along with traditional full mission simulator training to accommodate the changes in workplace and subsequent training needs to cope with newer technologies, e.g., autonomous, semi-autonomous, unmanned, etc., [44,45].

The human involvement onboard autonomous or remote-controlled ships has been the focus of discussion in literature. Several options have been proposed for the number of crews required onboard, i.e., the $3 \mathrm{M}$ (i.e., three masters) solution where three navigation officers with ICT knowledge, or MP (master-pilot) where one person will take over the navigation of ships once they reach certain pilot stations during deep sea voyages [11]. However, most discussion related to the autonomous ships in the literature caters to the navigational aspects and associated crew requirements of the ship than about the engineering aspects and crew. Therefore, this study adds value to the discussion about the role of engineers in the operation of degree- 2 autonomous ships, i.e., remotely controlled ships with seafarers onboard.

The study is based on the statistical analysis of a dataset derived from the Likert Scale. Hence, the general limitations related to employing the Likert Scale in research remain relevant for this study as well. Furthermore, the perception of early-stage marine engineers related to future autonomous ships may evolve over time, especially since their existing professional work experience is acquired from contemporary merchant vessels. Additionally, the variance in perception of the respondents could also be due to them being graduated from different MET institutions within the same country.

Future studies in consultation with classification societies, flag states, and other stakeholders involving the skill prediction for prospective seafarers could potentially benefit the training strategy and practices for marine engineers. Additional data collection from other developing nations and beyond could improve the generalization of the findings of this study.

\section{Conclusions}

This study investigated whether the current MET practices in Bangladesh as a representative of developing nations are perceived as sufficient by early-stage professional marine engineers, and whether the required competencies would be relevant in the future. The results indicate that even though the current MET practices in Bangladesh are suffi- 
ciently addressing the competency requirement to be able to communicate in English, a non-technical skill in nature, a few technical competencies related to electrical equipment, seaworthiness, and first-aid knowledge are not sufficiently addressed. At the same time, those technical competencies are perceived as significantly relevant for future degree-2 autonomous ships.

Since STCW convention mandates and recommends guidelines for MET all over the world, international and national policy stakeholders of Bangladesh could take notice of the findings to improve their existing MET facilities to ensure appropriate competency development of seafarers for the traditional shipping market. As a representative of developing nations, Bangladesh could set an example for other maritime nations, especially in the South-East Asia region, to chart out future directions for employing appropriate MET strategies for marine engineers. Future research to streamline MET practices at a global scale engaging both developed and developing nations would be a crucial move forward in the maritime domain.

Author Contributions: Conceptualization, H.M.T. and A.S.; methodology, Z.H.M. and H.M.T.; formal analysis, Z.H.M.; writing-original draft preparation, H.M.T.; writing-review and editing, S.N., A.S. and Z.H.M.; visualization, Z.H.M.; supervision, S.N.; project administration, S.N. All authors have read and agreed to the published version of the manuscript.

Funding: The authors would like to acknowledge the Centre of Excellence in Maritime Simulator Training and Assessment (SFU-COAST /10021) in Norway, funded by the Directorate for Higher Education and Competence (HK-dir) for their cooperation and facilitation for this research work.

Institutional Review Board Statement: Not applicable.

Informed Consent Statement: Not applicable.

Data Availability Statement: The data used in this study are available upon request from the corresponding author.

Acknowledgments: The authors would like to thank all survey participants for their valuable contribution.

Conflicts of Interest: The authors declare no conflict of interest. The funders had no role in the design of the study; in collection, analyses, or interpretation of data; in the writing of the manuscript; or in the decision to publish the results.

\section{References}

1. Ocean Shipping and Shipbuilding-OECD. Available online: https://www.oecd.org/ocean/topics/ocean-shipping/ (accessed on 17 September 2021).

2. Basak, S.K. A framework on the factors affecting to implement maritime education and training system in educational institutions: A review of the literature. Procedia Eng. 2017, 194, 345-350. [CrossRef]

3. Chauvin, C.; Lardjane, S.; Morel, G.; Clostermann, J.-P.; Langard, B. Human and organisational factors in maritime accidents: Analysis of collisions at sea using the HFACS. Accid. Anal. Prev. 2013, 59, 26-37. [CrossRef]

4. International Convention on Standards of Training, Certification and Watchkeeping for Seafarers, (STCW) 1978, as amended in 1995/2010. Int. Marit. Organ. 2011. Available online: https://www.imo.org/en/OurWork/HumanElement/Pages/STCW-ConvLINK.aspx (accessed on 2 October 2021).

5. Bolmsten, J.; Manuel, M.E.; Kaizer, A.; Kasepõld, K.; Sköld, D.; Ziemska, M. Educating the Global Maritime Professional—A case of collaborative e-learning. WMU J. Marit. Aff. 2021, 20, 309-333. [CrossRef]

6. Harati-Mokhtari, A.; Wall, A.; Brooks, P.; Wang, J. Automatic Identification System (AIS): Data reliability and human error implications. J. Navig. 2007, 60, 373-389. [CrossRef]

7. Brandsæter, A.; Knutsen, K.E. Towards a framework for assurance of autonomous navigation systems in the maritime industry. In Safety and Reliability-Safe Societies in a Changing World; CRC Press: London, UK, 2018; pp. 449-457.

8. de Vos, J.; Hekkenberg, R.G.; Banda, O.A.V. The impact of autonomous ships on safety at sea-a statistical analysis. Reliab. Eng. Syst. Saf. 2021, 210, 107558. [CrossRef]

9. Relling, T.; Lützhöft, M.; Ostnes, R.; Hildre, H.P. A human perspective on maritime autonomy. In Proceedings of the International Conference on Augmented Cognition, Las Vegas, NV, USA, 15-20 July 2018; Springer: Cham, Switzerland, 2018 ; pp. $350-362$.

10. Sharma, A.; Kim, T. Exploring technical and non-technical competencies of navigators for autonomous shipping. Marit. Policy Manag. 2021, 1-19. [CrossRef] 
11. Alop, A. The Challenges of the Digital Technology Era for Maritime Education and Training. In Proceedings of the 2019 European Navigation Conference (ENC), Warsaw, Poland, 9-12 April 2019; IEEE: Warsaw, Poland, 2019; pp. 1-5. [CrossRef]

12. Maritime Safety Committee (MSC), 98th Session. 2017. Available online: https://www.imo.org/en/MediaCentre/ MeetingSummaries/Pages/MSC-98th-session.aspx (accessed on 10 August 2021).

13. Bennabi, N.; Charpentier, J.F.; Menana, H.; Billard, J.-Y.; Genet, P. Hybrid propulsion systems for small ships: Context and challenges. In Proceedings of the 2016 XXII International Conference on Electrical Machines (ICEM), Lausanne, Switzerland, 4-7 September 2016; IEEE: Piscataway, NJ, USA, 2016; pp. 2948-2954.

14. Korberg, A.D.; Brynolf, S.; Grahn, M.; Skov, I.R. Techno-economic assessment of advanced fuels and propulsion systems in future fossil-free ships. Renew. Sustain. Energy Rev. 2021, 142, 110861. [CrossRef]

15. Sharma, A.; Kim, T.; Nazir, S.; Chae, C. Catching up with time? Examining the STCW competence framework for autonomous shipping. In Proceedings of the Ergoship Conference, Haugesund, Norway, 24-25 September 2019; pp. $24-25$.

16. Abutal, J.Y. The Problem of Recruitment and Retention of Qualified Maritime Educators in Maritime Academies in the Developing Countries: The Case of Philippine Merchant Marine Academy. Master's Thesis, World Maritime University, Malmö, Sweden, 2000

17. Lee, S. Strategy for Maritime Training in Higher Educational System in Developed Society. In Proceedings of the Korean Institute of Navigation and Port Research Conference; Korean Institute of Navigation and Port Research: Busan, Korea, 1993 ; pp. 3-13.

18. Šoškić, S.D.; Radojević, S.M.; Komazec, N.M. Maritime training Serbian Aotonomous vessel protection detachment. Annu. Navig. 2014, 21, 143-150. [CrossRef]

19. Internaitonal Chamber of Shipping. Heroes at Sea. 2020. Available online: https://www.ics-shipping.org/publication/annualreview-2020/ (accessed on 2 October 2021).

20. Todd, S. Global Supply Chain Crisis Could Deepen Because of Unvaccinated Seafarers-Lloyd's Loading List. 2021. Available online: https:/ / www.lloydsloadinglist.com/freight-directory/news/Global-supply-chain-crisis-could-deepen-becauseof-unvaccinated-seafarers/78715.htm\#.YRMIIVMzZTY (accessed on 11 August 2021).

21. TESDA, T. The Philippine Maritime Industry: Through the Years; Technical Education and Seafarer Development Authority (TESDA): Manila, Philippines, 2017.

22. GSO-Bangladesh, G.-B. Annual Report, 2018; Government Shipping Office: Chittagong, Bangladesh, 2018.

23. Islam, D.M.; Alamgir, M.Z.; Shaheen, M.A.; Mahmud, A. Seafarers Employment Issues: Bangladesh Perspective. Br. Med. J. 2019, 5, 181-192.

24. Short, R. Networking Maritime Education and Training in the Asia Pacific Region. Marit. Stud. 1996, 1996, 12-15. [CrossRef]

25. Butman, B. Study in standardizing marine engineering curriculum. In Maritime Security and MET; WIT Press: Southampton, UK, 2005; pp. 19-28.

26. Gierusz, W.; Lisowski, J. The control engineering education of marine engineers according to the IMO requirements contained in the STCW'95 Convention. Global J. Eng. Educ. 1998, 2, 231-238.

27. Ünsalan, D.; İzet-Ünsalan, K.-Ö. Marine Engineering Education for the 21st Century-Addressing the Oncoming Innovations in Ship Technology. In Proceedings of the 5th Balkan Region Conference on Engineering and Business Education/2nd International Conference on Engineering and Business Education, Sibiu, Romania, 15-17 October 2009. Available online: https://hdl.handle. net/20.500.12960/144 (accessed on 15 September 2021).

28. Jo, S.; D'agostini, E. Disrupting technologies in the shipping industry: How will MASS development affect the maritime workforce in Korea. Mar. Policy 2020, 120, 104139. [CrossRef]

29. Lokuketagoda, G. Training Engineers for remotely operated ships of the future. 19th Annu. Gen. Assem. AGA 2018 2018, 8 , 207-214.

30. Lloyd's Register Design Code for Unmanned Marine Systems. February 2017. Available online: https://www.lr.org/en/ unmanned-code/ (accessed on 15 September 2021).

31. DNV GL. Class Guideline-Autonomous and Remotely Operated Ships. DNV GL. 2018. Available online: http://rules.dnvgl. $\mathrm{com} / \mathrm{docs} / \mathrm{pdf} / \mathrm{dnvgl} / \mathrm{cg} / 2018-09 /$ dnvgl-cg-0264.pdf (accessed on 21 March 2021).

32. International Maritime Organization (IMO). IMO Takes First Steps to Address Autonomous Ships. 2021. Available online: https://imo.org/en/MediaCentre/PressBriefings/Pages/08-MSC-99-MASS-scoping.aspx (accessed on 21 March 2021).

33. International Maritime Organization. Working Group Report in 100th Session of IMO Maritime Safety Committee for the Regulatory Scoping Exercise for the Use of Maritime Autonomous Surface Ships (MASS); IMO Document MSC 100/WP.8; IMO: London, UK, 2018.

34. Taylor, D.A. 17-Watchkeeping and equipment operation. In Introduction to Marine Engineering; Taylor, D.A., Ed.; ButterworthHeinemann: Oxford, UK, 1983; pp. 331-336. [CrossRef]

35. Earthy, J.V.; Lützhöft, M. Autonomous ships, ICT and safety management. In Managing Maritime Safety; Routledge: Oxfordshire, UK, 2018; pp. 141-165.

36. Mallam, S.C.; Nazir, S.; Sharma, A. The human element in future Maritime Operations-Perceived impact of autonomous shipping. Ergonomics 2020, 63, 334-345. [CrossRef] [PubMed]

37. Manuel, M.E. Vocational and academic approaches to maritime education and training (MET): Trends, challenges and opportunities. WMU J. Marit. Aff. 2017, 16, 473-483. [CrossRef]

38. Hair, J.F. Multivariate Data Analysis; Pearson: London, UK, 2009. 
39. Bauk, S.; Ilčev, S.; Phewa, N. Maritime Education and Training (MET) Curriculum Challenges in the Twenty-First Century. In Proceedings of the 1st International Conference on Maritime Education and Developmenticmed, Durban, South Africa, 23-24 November 2020; pp. 163-171.

40. Aeni, N.; Jabu, B.; Rahman, M.A.; Ismail, H.; Bin-Tahir, S.Z. The Students' Needs in Maritime English Class at Ami Aipi Makassar, Indonesia. J. Lang. Teach. Res. 2018, 9, 1284. [CrossRef]

41. Ahmmed, R.; Sinha, B.S.; Khan, D.R.; Islam, D.M. A needs analysis of maritime English language skills for Bangladeshi seafarers to work on-board ships. Mar. Policy 2020, 119, 104041. [CrossRef]

42. Kaber, D.B.; Riley, J.M.; Tan, K.-W.; Endsley, M.R. On the design of adaptive automation for complex systems. Int. J. Cogn. Ergon. 2001, 5, 37-57. [CrossRef]

43. Demirel, E.; Mehta, C.R. Developing an effective maritime education and training system-TUDEV experiment. In Proceedings of the International Maritime Lawyers Association Conference, Accra, Ghana, 2009; pp. 1-11. Available online: https:/ / www.semanticscholar.org/paper/Developing-an-Effective-Maritime-Education-and-Mehta/df17b91c773a07696de3 ef94a5d9b8fc12cbc4a8 (accessed on 2 October 2021).

44. Kim, T.; Sharma, A.; Bustgaard, M.; Gyldensten, W.C.; Nymoen, O.K.; Tusher, H.M.; Nazir, S. The continuum of simulator-based maritime training and education. WMU J. Marit. Aff. 2021, 20, 135-150. [CrossRef]

45. Mallam, S.C.; Nazir, S.; Renganayagalu, S.K. Rethinking Maritime Education, Training, and Operations in the Digital Era: Applications for Emerging Immersive Technologies. J. Mar. Sci. Eng. 2019, 7, 428. [CrossRef] 